\title{
Protection of Owners or Holders of Rights to Trademarks of Imported Goods in Indonesia
}

\author{
Elfi Haris ${ }^{1}$, OK. Saidin ${ }^{2}$, Ningrum Natasya Sirait ${ }^{3}$, Maria Kaban ${ }^{4}$ \\ \{elfi.hariss@gmail.com ${ }^{1}$, saidin@usu.ac.id ${ }^{2}$, ningrum@usu.ac.id ${ }^{3}$, mariakabans@yahoo.com ${ }^{4}$ \} \\ Universitas Sumatera Utara, Indonesia ${ }^{1,2,3,4}$
}

\begin{abstract}
International trade is increasing following advances in information technology and globalization. One of the violations of law that may occur in international trade is a violation of the rights to a trademark. This study aims at describing the legal protection of trademark owners or right holders in Indonesia. This study uses a normative legal research method with primary and secondary data sources. The findings show that the protection for the owner or holder of the rights to a trademark given by the Government of Indonesia in import transactions is still limited to goods traded for commercial purposes. Protection of consignments and passenger baggage has not been provided. In addition, government protection is also passive because it must be based on the owner or holder of the rights to a trademark application to the Commercial Court. Then the Commercial Court issues a suspension order to the Directorate General of Customs and Excise. Another mechanism is through the recording of the rights to a trademark (recordation) at Customs and Excise. This implies that there are two trademark registration mechanisms in Indonesia. The Indonesian government should change the rules for protecting trademarks, especially in international trade, so the trademark owners' or holders' rights and consumer rights are appropriately protected.
\end{abstract}

Keywords: IPR, Trademark, Import, Customs and Excise

\section{Introduction}

In the current era of globalization, international trade is snowballing. International trade is a trade between countries that includes sending goods out of the country (exports) or bringing goods into the country (imports). Professor Erman Rajagukguk argues that international trade relies a lot on intellectual property rights (IPR). Technology transfer from developed countries to developing countries can only take place if developing countries respect the IPR of developed countries [1].

Bainbridge states that Intellectual Property Rights are an area of law concerning legal rights associated with creative effort or commercial reputation and goodwill [2]. Meanwhile, Saidin says that IPR is a material right, the right to something that comes from the brain's work, the work of the ratio [3]. Two rights can be attached to an object: first, the right to tangible object (material), i.e., the physical right to the object itself, and the second, the right to immaterial object, i.e., the Intellectual Property Rights (IPR) to the object.

Although IPR is an intangible right, it is still recognized as property and must be protected. John Locke, a natural law figure who laid the foundations of thinking about human rights, in his book "Two Treaties on Civil Governmental", stated that since birth, humans have had natural rights, which are also called basic rights. These basic rights are the right to life, freedom and 
independence, and the right to property or the right to own something. To maintain and guarantee these basic rights, the people enter into an agreement that gives birth to a state. Therefore, the state should protect basic rights.

Protection on IPR is also a consequence of being a country that ratifies The Agreement on Trade-Related Aspect of Intellectual Property Rights (TRIPs). Based on Law Number 7 of 1994, Indonesia is obliged to provide equal protection to its citizens and citizens of other countries participating in the TRIPs agreement. Whatever is provided to its citizens must also be provided to the citizens of the other participating countries [4]. The Indonesian government must protect IPR from forgery, abuse, and other acts of irregularities.

To control imports or exports of goods resulting from IPR violations, e.g., violation of the rights to a trademark, the Directorate General of Customs and Excise is appointed as the gatekeeper of the Indonesian customs area. Although several regulations have been issued to protect violations of imported goods resulting from violations of trademarks, currently circulation of imported goods allegedly violating trademark rights in the territory of the Republic of Indonesia is still found. Therefore, it is necessary to do a study related to the following problems:

a. The extent to which the protection of trademark rights is provided to imported goods in Indonesia.

b. The mechanism for protecting trademark rights to imported goods in Indonesia.

\section{Research Method}

This study uses a normative legal research method, a scientific research procedure, to find the truth based on the scientific logic of law from the normative side [5]. The object of this study includes primary legal materials in the form of statutory regulations and secondary legal materials such as law books, journals, articles, and other relevant sources. The data illustrate the extent to which the protection of the owner or holder of rights to a trademark can be guaranteed for their imported goods entering Indonesia.

\section{Results and Discussion}

\subsection{Trademark in Indonesia}

Law Number 15 of 2001 concerning Trademarks defines a trademark as a sign in the form of image, name, word, letters, numbers, color arrangement, or a combination of these elements which has distinctive power and is used in trading activities of goods or services. In an almost similar definition, Philip Kotler states that a trademark is a name, term, sign, symbol, design, or a combination thereof that shows the identity of the product maker or seller [6]. Furthermore, Saidin states that with a trademark, the product of similar goods or services can be distinguished based on their origin, quality, and assurance of the product's originality [3].

A trademark is basically a sign of identifying the origin of goods and or services (an indication of origin) from a company with goods and or services from other companies [7]. Every company must care about the importance of its product trademark because the trademark will be introduced to the public and become a guarantee of the product quality. Moreover, the increasing popularity of advertising leads to difficulties in selling a product without a trademark. 
It will be challenging to advertise mineral water, for example, without any specific trademark. People buy mineral water by mentioning its trademark, not its type.

David I. Bainbridge argues that trademarks can be seen as serving two main purposes: first, reflecting the fact that a registered trademark is an item of property, to protect business reputation and goodwill, and, secondly, to protect consumers from deception [2]. Thus, we can understand that the law enforcement related to trademarks does guarantee not only the rights of trademark owners or holders but also guarantees the rights of consumers to obtain goods of genuine quality.

Protecting the owners or holders of the rights to a trademark is a mandate of the law. There are two systems of trademark protection: declarative system and constitutive system. The declarative system will protect the first user of the trademark, while in the constitutive system, the protection is provided to the party registering the mark. Indonesia adheres to the constitutive system, so there is an obligation to register a trademark to obtain state protection. In 2019, there were 90,879 trademarks registered in Indonesia, $13.47 \%$ of which were registered trademarks from foreign countries. The data show the high expectation of the owners or holders of the rights to a trademark to get protection in Indonesia.

Table 1. Trademark Registration in Indonesia from 2015 to 2019

\begin{tabular}{lccccc}
\hline \multirow{1}{*}{$\begin{array}{c}\text { Trademark } \\
\text { Registration }\end{array}$} & \multicolumn{5}{c}{ Application for Entry } \\
\cline { 2 - 6 } \multicolumn{1}{c}{} & $\mathbf{2 0 1 5}$ & $\mathbf{2 0 1 6}$ & $\mathbf{2 0 1 7}$ & $\mathbf{2 0 1 8}$ & $\mathbf{2 0 1 9}$ \\
\hline Domestic & 46.298 & 49.369 & 51.902 & 56.575 & 69.004 \\
Foreign & 15.492 & 15.994 & 16.466 & 12.741 & 12.245 \\
Total & 61.790 & 65.363 & 68.368 & 69.316 & 81.249 \\
\hline
\end{tabular}

Source: Annual Report 2019 of Directorate General of IPR, Ministry of Law and Human Rights

\subsection{Import Mechanism in Indonesia}

Import is an activity of bringing goods into the Indonesian customs area, which includes land, water, and the air space above them and certain places in the Exclusive Economic Zone and continental shelf. The entrance of imports to Indonesia is through the sea, air, and land routes. However, along with the development of technology, the entrance of imports to Indonesia is growing, which can be through pipelines, cable networks, or wireless networks.

Goods arriving in Indonesia are unloaded at the seaport and then hoarded in a Temporary Storage (TS). In some instances, hoarding can be done at a place other than TS with a permit from the Customs and Excise. The hoarding is intended to wait for the customs clearance process. In this process, Customs and Excise ensure that the imported goods meet the applicable provisions. Imported goods complying with the provisions will be given an import agreement, while imported goods that do not meet the provisions will be enforcement. In certain cases, imported goods can be re-exported, i.e., by sending them back to the country of origin. This can occur due to delivery errors; the owner cannot fulfill the licensing conditions or other reasons. The import process scheme can be described as follows: 


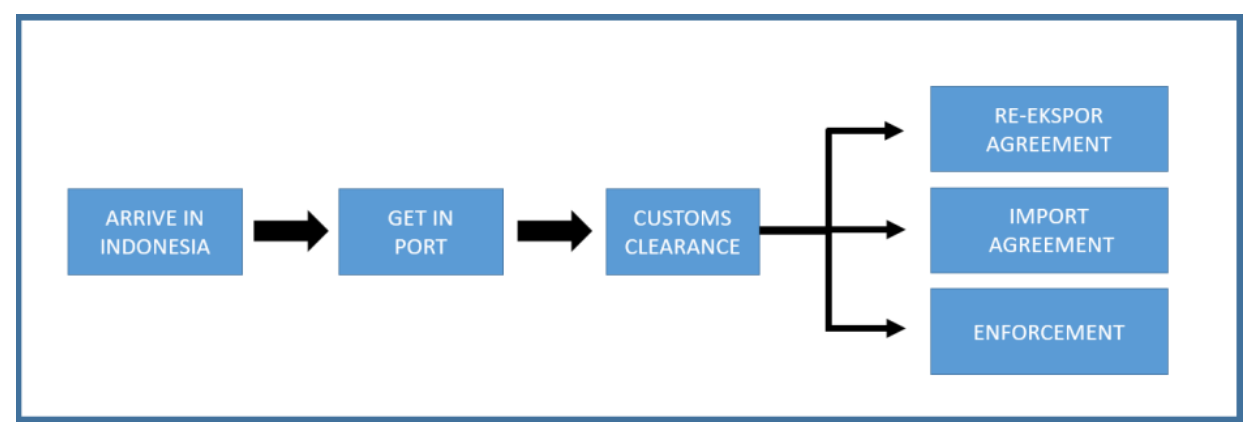

Fig. 1. Import Process Scheme in Indonesia.

Article 82 of Law Number 17 of 2006 authorizes Customs and Excise to conduct customs inspection on imported or exported goods after submitting customs notification. The customs inspection system consists of 2 (two) types: the self-assessment and ex-officio assessment systems [8]. In addition, Article 82 regulates the self-assessment inspection system by stating that the inspection is conducted after the customs notification is submitted. This customs inspection is carried out to ensure that the imported goods follow what has been notified, not goods that are prohibited or restricted to import.

There are several models of import customs notification, which have been adjusted to the procedures for the entry of imported goods into Indonesia, including:

a. The type of notification by a general importer or producer importer with legal entity status is called Notification for Import of Goods (NIG). This import is carried out by a company with a Business Identification Number (BIN) with the status of an importer.

b. Notification of the baggage of passengers and crews of transportation means is called Customs Declaration (CD). In certain cases, a Special Goods Import Declaration (SGID) can be used.

c. Notification of import of consignments is called Consignment Note (CN). In certain cases, a Special Goods Import Declaration (SGID) can be used. These imports are carried out by courier service companies and marketplaces that are registered as importers.

The biggest import in Indonesia is using NIG. The import of consignments has begun to increase in recent years due to the increasing online shopping. Various goods are sent through courier services, ranging from goods with low values to high values and local brands to wellknown brands. The same case is applicable in the imports brought directly by passengers. Passengers take advantage of the exemption value of up to USD 500 per passenger to shop overseas and be brought to Indonesia as souvenirs and sometimes merchandise.

\subsection{Protection of Owners or Holders of Rights to Trademark against Imported Goods}

The speed of the releasing process of imported goods from a seaport is important in a series of national logistics systems. In addition, one of the indicators used by the World Bank in defining the level of ease of doing business in a country is trade across the border. Therefore, the process of checking or law enforcement on imported goods at the seaport must be precisely measurable and shall not result in high costs for national logistics. Based on the data reported by the World Customs Organization (WCO) member countries, one form of customs crime is 
counterfeiting or imitating other people's products [9]. The term "counterfeiting or imitating other people's products" in legal language is an IPR infringement.

The legal basis for Customs and Excise to supervise imports violating IPR is Article 54 of Law Number 17 of 2006, which reads, "At the request of the owner or holder of the rights to a trademark or copyright, the head of the commercial court can issue a written order to Customs and Excise officials to temporarily suspend the release of imported or exported goods from the customs area which, based on sufficient evidence, are suspected to be the results of infringement of protected trademarks and copyrights in Indonesia".

Supreme Court Regulation Number 6 of 2009 mentions the authority of Customs and Excise officials as regulated in Article 54 with the term judicial temporary suspension. Meanwhile, among Customs and Excise, the term is known as judicial schema [10]. In this case, the position of Customs and Excise is passive because suspending imported goods suspected of violating copyright or trademark can only be done if there is a written order from the head of the commercial court.

The obstacle in the process of temporary suspension through this judicial schema is associated with time. The process of releasing goods from the seaport is very fast. For imported goods with the green line service category, the time required from submitting customs documents to approval for releasing the goods is only in a matter of minutes. At Belawan Seaport, the average time for hoarding, from the time the goods are unloaded from the ship (stripping) to the goods leaving the seaport (Gate out), is less than 3 (three) days. Therefore, if the owner or holder of the rights to a trademark will apply for a temporary suspension, it must be done before the goods leave the seaport. In other words, the time to apply for a temporary suspension is less than 3 (three) days.

Considering the promise of the commercial court service that issuing a temporary suspension is 2 (two) days after the registration of the application at the commercial court [11], A temporary suspension is unlikely to be implemented if it does not have sufficient information before imported goods suspected of violating the trademark arrive at the seaport.

In addition to the temporary suspension authority based on the judicial schema, Customs and Excise officials are also given suspension authority based on the position (ex-officio schema) [10]. This authority is regulated in Article 62 of Law Number 10 of 1995, which states that suspending the release of imported or exported goods can also be carried out because of the position of the Customs and Excise Officials. Nevertheless, this can only be done if there is sufficient evidence that the goods are or originate from a violation of rights to a trademark.

For a suspension using an ex-officio schema mechanism, the owner or holder of a trademark must submit a recordation application to Customs and Excise followed by the appointment of an examiner with the capability of identifying the authenticity of the recorded trademark. The term Recordation is used in Article 1 point 17 of the Finance Minister Regulation Number 40/PMK.04/2018 concerning Recordation, Prevention, Protection, Temporary Suspension, Monitoring, and Evaluation to Control Import or Export of Goods Resulting from Violation of Intellectual Property Right. Recordation means inputting Intellectual Property Right data into the Directorate General of Customs and Excise database. If the recordation is approved, the trademark is inputted into the customs recording application system (CEISA IPR).

The obstacle in this ex-officio schema is related to the recordation process carried out by the owner or holder of the right. Due to the obligation to register a trademark at the Directorate General of Intellectual Property Rights, Ministry of Law and Human Rights, as stipulated in Law Number 15 of 2001 and the recordation obligation at the Directorate General of Customs and Excise, Ministry of Finance, then two registration processes must be carried out by the 
owner or holder of the rights to a trademark. From the business communities perspective, all work units of ministries and local governments are integrated into the system of the Unitary State of the Republic of Indonesia. The registration of trademarks in Indonesia should only be done once. Furthermore, the ministries requiring trademark-related data can make data exchange agreements.

Based on data in the Intellectual Property Recording Application System of the Directorate General of Customs and Excise, in March 2021, only 15 owners or holders of Intellectual Property Rights were recorded in the CEISA IPR Application System, 13 of which were related to trademarks [12]. This number is far from the number of trademarks registered in the Trademark Registration System of the Directorate General of IPR. In 2019, it reached 90,879 trademarks. This condition might be caused by ignorance or reluctance of the right owners or holders to a trademark to do recordation. In fact, they also really hope for protection and assurance from the government in both domestic and international trade.

Another article that regulates IPR is Article 55 of Law Number 10 of 1995, which states that to apply for a temporary suspension, the right owner or holder must submit a guarantee in the form of an operational cost of IDR 100,000,000.00 [13]. For a judicial schema, the guarantee must be submitted by the right owner or holder simultaneously as submitting a suspension order from the commercial court. Meanwhile, for an ex-officio schema, the guarantee must be submitted after the notification of temporary suspension submitted by Customs and Excise to the right owner or holder.

Temporary suspension, both for the judicial schema and ex-officio schema, is not applied to imports of consignments or imports brought directly by passengers. The import mechanism through consignments is developing so rapidly that it potentially becomes an entry point for goods resulting from violation of the rights to a trademark. As a member of the World Trade Organization (WTO) that has ratified the TRIPs, Indonesia must provide complete and intact protection of trademark rights while still paying attention to the history and culture of Indonesian law.

Even though trademark infringement in international trade is a global problem, it will be complicated to formulate a rule that applies in all countries (unification), even among countries that adhere to the civil law system. There are linguistic differences that may lead to different interpretations. Another factor that must be considered is the problem of cultural differences among various systems. Many legal writers and historians have described the uniqueness of various legal systems and the relationship between the law and the culture [14].

At the regional level, ASEAN countries also see the importance of protecting Intellectual Property Rights for the member countries, especially in realizing the ASEAN Economic Community (AEC). For this reason, the ASEAN Framework Agreement on Intellectual Property Cooperation was signed in Bangkok on December 15, 1995. The most critical points of this Agreement are: (i) it recognizes the vital role of IPR in the implementation of trade and investment flows among ASEAN Member Countries and the importance of cooperation in intellectual property right in the ASEAN regions; and (ii) it expresses a desire to foster closer cooperation in the field of IPR and related fields to provide a solid basis for economic progress, the realization of ASEAN Free Trade Area, and prosperity among ASEAN Member Countries [15].

Therefore, Indonesia must reformulate the rules for the protection of trademark owners or holders, especially in the context of international trade, while still paying attention to the values of the Indonesian nation, which are crystallized in the values of Pancasila.

Several regulations need to be revised, like Law Number 20 of 2016 concerning Trademark and Geographical Indication. The Law should include some additional articles regarding 
trademark protection of imported goods and trademark registration database management. Similarly, Law Number 17 of 2016 concerning Customs should add some articles regarding imported good intellectual property rights. It should cover not only copyright and trademark protection but also cover all types of intellectual property rights. Moreover, the regulation should include ex-officio schema temporary suspension because the available law only regulates judicial schema. Furthermore, the legal protection should be expanded to all import mechanisms, including hand-carry baggage, postal and courier services, and e-commerce. The law should also regulate a more straightforward temporary suspension procedure.

\section{Conclusion}

The research finally concludes that:

a. The regulations on controlling infringement of trademarks of imported goods should be revised by adding the need for broader supervision on imports of consignments and imports of passenger baggage.

b. The mechanism for protecting the rights to a trademark for imported goods should be simplified, including by making a data link for registering the trademark of the Directorate General of IPR to the Directorate General of Customs and Excise. This mechanism can eliminate the recordation process at Customs and Excise and eliminate guarantees for operational costs.

\section{References}

[1] E. Rajagukguk, "Hak milik intelektual dan putusan-putusan pengadilan," SALAM J. Sos. dan Budaya Syar-i, vol. 1, no. 1, 2014.

[2] D. I. Bainbridge, "Intellectual Property.” New York: Longman Pearson, 2018.

[3] Saidin, "Aspek Hukum Hak Kekayaan Intelektual,/(Intellectual Property Rights),” 2002.

[4] F. X. Margono, "Dampak implementasi TRIPS (Trade Related Intellectual Property Rights) Agreement dalam GATT/WTO terhadap penegakan hukum dan penyelesaian sengketa hak cipta." UNIVERSITAS TARUMANAGARA, 2004.

[5] J. Ibrahim, "Teori dan metodologi penelitian hukum normatif," Malang Bayumedia Publ., vol. 57, 2006.

[6] P. Kotler and Amstrong, "Prinsip-Prinsip Pemasaran," Erlangga, Jakarta, 2001.

[7] R. Jened, Hukum merek (trademark law): dalam era global dan integrasi ekonomi. Prenadamedia Group, 2015.

[8] Sutardi, Catatan dan Komentar Terhadap Undang-Undang Kepabeanan. Jakarta, 2016.

[9] A. Rachman, Intelijen Pabean Indonesia. Jakarta, 2016.

[10] Direktorat Jenderal Beda dan Cukai, "Sosialisasi HAKI dan Pra-Survei," 2018.

[11] Pemerintah Republik Indonesia, Peraturan Mahkamah Agung Republik Indonesia Nomor 6 Tahun 2019. 2019.

[12] Direktorat Jenderal Bea dan Cukai, "Sistem Informasi dan Otomasi Kepabeanan dan Cukai (CEISA)," Sistem Aplikasi Perekaman Kekayaan Intelektual. .

[13] Pemerintah Republik Indonesia, Peraturan Pemerintah Nomor 20 Tahun 2017 tentang Pengendalian Impor atau Ekspor Barang Yang Diduga Merupakan Atau Berasal dari Hasil Pelanggaran Hak Kekayaan Intelektual. 2017.

[14] P. De Cruz, "Perbandingan Sistem Hukum, Common Law, Civil Law dan Socialist Law," Bandung. Nusa Media, 2010.

[15] ASEAN Intellectual Property Portal, “About." [Online]. Available: 
https://www.aseanip.org/About. 